\title{
Pensononowoor
}

2015, vol. 74, 43-57

http://dx.doi.org/10.12657/denbio.074.005

Wojciech Kraj

\section{Chlorophyll degradation and the activity of chlorophyllase and Mg-dechelatase during leaf senescence in Fagus sylvatica}

\author{
Received: 21 August 2014; Accepted: 25 March 2015
}

\begin{abstract}
The induction and course of autumn leaf senescence in early, intermediate and late phenological forms of beech (Fagus sylvatica L.) was studied by analysing the contents of chlorophyll a and b, chlorophyll degradation products and the activities of chlorophyllase and Mg-dechelatase. Studies were conducted in two beech stands differing in the date of senescence onset. Leaf samples were collected from July to October in 2007 and 2009. The main trigger of leaf senescence in beech was a temperature drop occurring in parallel with the appropriate photoperiod. The early phenological form was the most sensitive to temperature. Chlorophyll degradation in senescing leaves of this form occurred in three stages, which strongly coincided with the dates of sudden temperature drops. These stages were less visible in the intermediate form, whereas chlorophyll degradation in the late form was the most stable and occurred in two stages. The fraction of chlorophyllides and phaeophytin in relation to chlorophylls in the early phenological form was significantly higher than that in the late form. Biochemical analyses indicate that pigment dephytylation associated with an increase in chlorophyllase activity is an early reaction of chlorophyll degradation, whereas the Mg-dechelating reaction was much less important. The correlation coefficients between the proportion of chlorophyllides and chlorophyll content for the early, intermediate and late phenological forms were $-0.90,-0.87$ and -0.72 , respectively, providing evidence of chlorophyllase activity in vivo. The activity of chlorophyllase depended significantly on the phenological form. All chlorophyll degradation parameters were highly correlated with temperature changes during senescence. The early phenological form was characterised by the highest correlation coefficients.
\end{abstract}

Keywords: beech, autumn senescence, phenological forms, chlorophyll-degrading enzymes

Address: Department of Forest Pathology, Mycology and Tree Physiology, Agricultural University in Cracow, Al. 29 Listopada 46, 31-425 Cracow; e-mail: rlkraj@cyf-kr.edu.pl

\section{Introduction}

European beech (Fagus sylvatica L.) is one of the most widespread and important deciduous trees in Europe. This species displays a large degree of variability in its morphological, physiological and genetic traits (Dolnicki and Kraj 2001; Kraj and Sztorc 2009). On the basis of these traits, different ecotypes, geographical races and, in particular, phenological forms have been described (Dolnicki and Kraj 2001; Hejtmánek 1956). Bud flushing and autumn leaf senescence differ in their onset and course both among 
populations and among individuals within particular populations. It is believed that the occurrence of early and late phenological forms whose growing seasons differ in their beginning and end dates is one of this species' defence strategies against the unfavourable impact of environmental conditions, especially spring and autumn frosts (Dolnicki and Kraj 2001; Kraj and Sztorc 2009). The timing of leaf senescence and the variability of this trait are manifested in populations with a frequency that depends on the interaction of genotypes and environmental conditions (Schieber 2006).

Senescence is the final phase of leaf development, which culminates in the death and shedding of leaves. This process comprises a highly regulated series of biochemical events, during which organelles, membranes and macromolecules are broken down and nutrients such as amino acids, sugars and minerals are reclaimed for export out of the senescing leaves to be stored as reserves in the stem, bark or roots for new leaf growth in the spring (Coleman et al. 1993; Srivastava 2002). Chlorophyll and chloroplast proteins are degraded relatively early during autumn senescence in trees, i.e., in the absence of pathogens, insects and extreme changes in temperature, light and abnormal precipitation (Hortensteiner 2006). In deciduous trees, the timing of leaf senescence defines leaf lifespan and determines the timing of carbon assimilation, the tree growth rate and the productivity of ecosystems (Delpierre et al. 2009; Kraj 2014). Trees growing in same site in a specified region generally exhibit low year-to-year variability in the timing of leaf senescence (Morecroft et al. 2003). Some of the environmental, biochemical and molecular factors affecting the onset of leaf senescence have been identified, but understanding their interactions remains a challenge (Lim et al. 2007). The environmental factors that trigger leaf senescence have been the subject of several studies in deciduous tree species, including Fagus sylvatica, Quercus petraea, Quercus robur and Populus tremula (Delpierre et al. 2009; Fracheboud et al. 2009; Schuster et al. 2014; Škvareninová and Snopková 2011). The main factors defining the onset of leaf senescence in beech are decreasing temperature and photoperiod (Menzel 2003; Schuster et al. 2014). However, the critical day length for the onset of leaf colouring is largely unknown, except for the findings based on the phenological, rather than biochemical, observations reported by Schuster et al. (2014). The relative contributions of decreasing temperature and photoperiod to the induction of leaf senescence are not well defined (Delpierre et al. 2009).

The natural breakdown of chlorophyll occurs during specific plant development stages, such as leaf senescence (Matile et al. 1996; Takamiya et al. 2000). However, the degradation of chlorophyll in the au- tumn-senescing leaves of woody plants has received little attention compared to biochemical research on chlorophyll catabolism in annual plants, and the regulation of this process during different physiological and developmental stages of leaf life, including autumn senescence, is still not well understood. During senescence, chlorophyll-protein complexes are disassembled and the pigments are liberated. Free chlorophylls are highly photoactive compounds that can generate free radicals, causing damage to cell membranes and increasing the rate of leaf senescence. Therefore, chlorophyll breakdown pathways must be tightly regulated to avoid the accumulation of photodynamic chlorophyll intermediate metabolic products (Hortensteiner 2006; Matile et al. 1996).

The pathways of chlorophyll breakdown comprise several enzymatic reactions, which are localised in chloroplasts and vacuoles. There are two types of initial reactions in chlorophyll degradation: the removal of phytol by chlorophyllase to produce chlorophyllides (Hortensteiner 2006) and the elimination of $\mathrm{Mg}^{2+}$ from chlorophylls or chlorophyllides by Mg-dechelatase or metal-chelating substances to produce phaeophytin or phaeophorbide, respectively (Hortensteiner 2006; Tang et al. 2000).

The objective of this work was to characterise the influence of phenological form on the course of chlorophyll degradation and autumn leaf senescence in beech trees. Studies were carried out on two beech stands over two growing seasons, which enabled the determination of the effects of climatic conditions on the course of natural leaf senescence. The changes in the chlorophyll content and the products of the early stages of chlorophyll degradation, i.e., chlorophyllides and phaeophytin, were determined. The activities of chlorophyllase and Mg-dechelatase in autumn leaf senescence were also measured. These experiments demonstrated the relative contributions of these enzymes to chlorophyll degradation and the appearance of senescence symptoms.

\section{Materials and Methods}

\section{Plant material}

Plant material was collected in two young stands of beech (Fagus sylvatica L.) trees (15 years old) in 2007 and 2009. The beech stands differed in the presence of autumn phenological phases. The study sites were located in the Krzeszowice Forest District near Cracow, Poland. The sites were designated as Mlynka (near Mlynka village) (lat. 50 $06^{\prime} 28^{\prime \prime} \mathrm{N}$, long. $19^{\circ} 40^{\prime} 53^{\prime \prime}$, alt. $294 \mathrm{~m}$ ) and Kopce (from Kopce Inspectorate) (lat. $50^{\circ} 06^{\prime} 13^{\prime \prime} \mathrm{N}$, long. 19 $39^{\prime} 48^{\prime \prime} \mathrm{E}$, alt. $316 \mathrm{~m}$ ). Between 2004 and 2008, in each stand, approximately 200 trees were visually scored for au- 

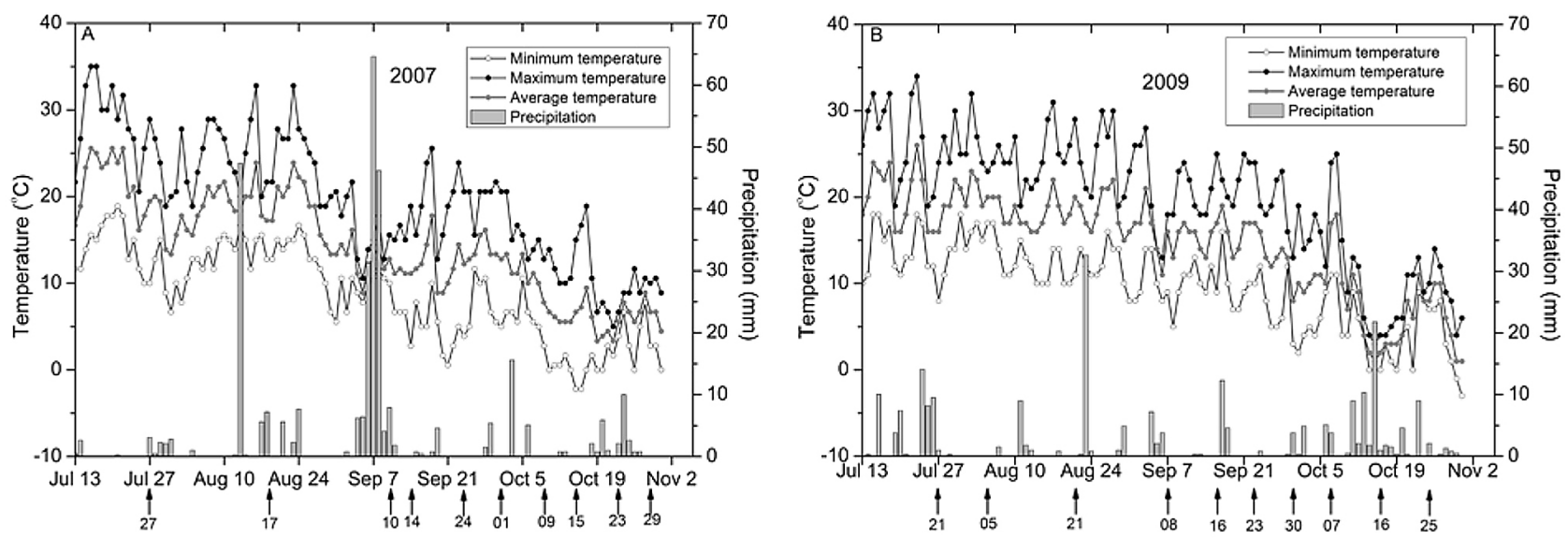

Fig. 1. Weather conditions during the 2007 (A) and 2009 (B) sampling periods. The grey bars represent the daily precipitation in millimetres. The lines correspond to the maximum, minimum and average temperatures $\left({ }^{\circ} \mathrm{C}\right)$. The arrows indicate the sampling dates, and the numbers below the arrows indicate the next day of the month

tumn senescence. Individuals of early, intermediate and late phenological forms, differing in the date of leaf senescence onset, were selected on the basis of a modified scale of autumnal phenological stages described by Stachak (1965) and marked at the beginning of October. Individuals of phenological forms showed 50\%, 20\% and 5-10\% discoloured leaves during marking. Fifteen individuals were randomly chosen from each group. From these trees, leaves were collected from neighbouring one-year-old sunlit shoots growing under uniform sun exposure on the south side of the crown. In both years, the samples were collected on 10 occasions from the end of July to the end of October between approximately 9 and $11 \mathrm{am}$. The sampling dates are given in Fig. 1A and $1 \mathrm{~B}$. The leaves were frozen with liquid nitrogen and then ground into powder. For dry weight measurements, $100 \mathrm{mg}$ of leaf powder was dried for $72 \mathrm{~h}$ at $70^{\circ} \mathrm{C}$ until a constant weight was reached.

\section{Analytical methods}

\section{Chlorophyll and chlorophyll degradation products}

Chlorophyll a and chlorophyll b were extracted in ice-cold $80 \%(\mathrm{v} / \mathrm{v})$ acetone from $50 \mathrm{mg}$ of leaf powder. The absorbance of the leaf extracts was measured on a UV-VIS spectrophotometer (Thermo Fisher Scientific, Waltham, MA, USA) at 646 and 663 $\mathrm{nm}$. The chlorophyll concentrations were calculated using the Lichtenthaler and Wellburn (1983) formulae and were expressed in $\mathrm{mg} \mathrm{g}^{-1}$ dry weight.

To analyse the in vivo activity of chlorophyll-degrading enzymes (chlorophyllase and Mg-dechelatase), the chlorophyllide a, chlorophyllide b and total phaeophytin contents in senescing leaves were measured in 2007 in both beech stands. Analyses of chlorophyllides were performed as follows: an equal volume of hexane was added to the chlorophyll ex- tract to remove pigments. The mixture was shaken vigorously, and the absorbance of the lower phase was measured at 667 and $651 \mathrm{~nm}$. Chlorophyllide $a$ and chlorophyllide $b$ levels were calculated using the extinction coefficients $76.79 \mathrm{mM}^{-1} \mathrm{~cm}^{-1}\left(\mathrm{~A}_{667 \mathrm{~nm}}\right)$ and $47.04 \mathrm{mM}^{-1} \mathrm{~cm}^{-1}\left(\mathrm{~A}_{651 \mathrm{~nm}}\right)$, respectively (Porra et al. 1989), and expressed as the proportion of the chlorophyll a + chlorophyllide $\mathrm{a}$ and chlorophyll $\mathrm{b}+$ chlorophyllide $\mathrm{b}$ content.

To determine the total phaeophytin content in leaves, all of the chlorophyll present in the extracts was converted to phaeophytin by adding $25 \% \mathrm{HCl}$ to the supernatant, and the absorbance was read at 666 and $655 \mathrm{~nm}$. The phaeophytin concentration was calculated using the Vernon formulae (Vernon 1960). The content of phaeophytin in leaves was determined by subtracting the levels of chlorophylls in the original solution from the total phaeophytin obtained after adding $\mathrm{HCl}$ and expressed as the proportion of the total chlorophyll content.

\section{Chlorophyllase and Mg-dechelatase activity determination}

\section{Preparation of acetone powder}

A total of $200 \mathrm{mg}$ of leaf powder was homogenised with $4 \mathrm{ml}$ of pre-chilled acetone $\left(-20^{\circ} \mathrm{C}\right)$ and then centrifuged at $5500 \times \mathrm{g}$ for $15 \mathrm{~min}$ at $4^{\circ} \mathrm{C}$, and the precipitate was collected. The cold-acetone extraction was repeated several times to completely remove chlorophylls and carotenoids. Subsequently, $0.5 \mathrm{ml}$ of diethyl ether was added to remove the acetone. The acetone powder was dried in a vacuum and stored at $-20^{\circ} \mathrm{C}$ until use.

\section{Enzyme extraction}

The acetone powder $(50 \mathrm{mg}$ ) was homogenised in ice-cold $0.1 \mathrm{M}$ potassium phosphate buffer, $\mathrm{pH} 7.8$, containing $0.5 \%(\mathrm{v} / \mathrm{v})$ Triton X-100, $5 \%$ polyvinylpo- 
lypyrrolidone (PVPP), 2 mM EDTA and $1 \mathrm{mM}$ DTT. The mixture was stirred for $1 \mathrm{~h}$ at $4^{\circ} \mathrm{C}$ and centrifuged. The protein solution was used to determine the chlorophyllase and Mg-dechelatase activity.

\section{Preparation of enzyme substrates}

Chlorophyll a was prepared from spinach leaves according to Janave (1997). Spinach leaves were ground in liquid nitrogen and homogenised in cold acetone $\left(-20^{\circ} \mathrm{C}\right)$. The extract was centrifuged at 5500 $\times \mathrm{g}$ for $15 \mathrm{~min}$ at $4^{\circ} \mathrm{C}$ to remove insoluble materials. The supernatant was precipitated with a dioxane/ acetone mixture (Iriyama et al. 1974; Janave 1997). Distilled water was added dropwise until a chlorophyll precipitate was formed. The precipitate was kept on ice for $1 \mathrm{~h}$ in the dark, centrifuged at 14700 $\times \mathrm{g}$ for $15 \mathrm{~min}$ at $4^{\circ} \mathrm{C}$ and resuspended in acetone. The acetone solution of chlorophyll was treated with dioxane and distilled water again, kept on ice and resuspended in a small amount of acetone. The chlorophyll concentration was determined spectrophotometrically at 646 and $663 \mathrm{~nm}$ using the Lichtenthaler and Wellburn formulae. The chlorophyll was stored at $-20^{\circ} \mathrm{C}$ until the individual pigments were separated using sugar column chromatography (Perkins and Roberts 1962), resuspended in 100\% acetone and used as the substrate for the chlorophyllase activity assay.

Chlorophyllin was prepared from chlorophyll according to Vicentini et al. (1995). Petroleum ether was added to chlorophyll solution in $80 \%$ acetone $(1: 1, v / v)$ and mixed vigorously, and the ether phase was collected. The petroleum phase was washed twice with distilled water and mixed with $30 \%(\mathrm{~m} / \mathrm{v})$ $\mathrm{KOH}$ in methanol. The precipitated chlorophyllin was centrifuged at $5500 \times \mathrm{g}$ for $15 \mathrm{~min}$ at $4^{\circ} \mathrm{C}$ and dissolved in distilled water. The chlorophyllin solution was adjusted to $\mathrm{pH} 9$ with tricine. The chlorophyllin was stored in $-20^{\circ} \mathrm{C}$ and used as the substrate for the Mg-dechelatase assay.

\section{Chlorophyllase activity}

For the chlorophyllase assay, the following reaction mixture was used: $50 \mathrm{mM}$ potassium phosphate buffer, $\mathrm{pH} 7.8,0.15 \%(\mathrm{v} / \mathrm{v})$ Triton X-100, 1 $\mu \mathrm{M}$ chlorophyll a, $16 \%$ (v/v) acetone and $200 \mu \mathrm{l}$ of enzyme solution in a total volume of $2 \mathrm{ml}$. The reaction mixture was incubated in a water bath at $37^{\circ} \mathrm{C}$. After $15 \mathrm{~min}$, the reaction was stopped by adding 7.5 $\mathrm{ml}$ of cold hexane/acetone (7:3). The mixture was vigorously stirred and centrifuged at $5500 \times$ g for $5 \mathrm{~min}$ at $4^{\circ} \mathrm{C}$ for phase separation. The upper phase contained the remaining chlorophyll, and the lower phase contained chlorophyllide a. Chlorophyllase activity was determined spectrophotometrically by measuring chlorophyllide formation at $667 \mathrm{~nm}$ using the absorption coefficient $76.79 \mathrm{mM}^{-1} \mathrm{~cm}^{-1}$. One unit of chlorophyllase was defined as the amount of enzyme necessary to catalyse the production of $1 \mu$ mole of chlorophyllide per minute.

\section{Mg-dechelatase activity}

Mg-dechelation activity was assayed spectrophotometrically using the chlorophyllin solution. The following reaction mixture was used: $50 \mathrm{mM}$ Tris-tricine buffer, $\mathrm{pH} 8.8$, chlorophyllin to yield a final concentration of $98 \mathrm{nM}\left(\mathrm{A}_{686 \mathrm{~nm}}=0.2\right)$ and $200 \mu$ l enzyme extract in a total volume of $1.5 \mathrm{ml}$. The control treatment did not contain enzyme extract. The mixture was incubated at $37^{\circ} \mathrm{C}$, and $\mathrm{Mg}$-dechelation activity was assayed by measuring the increase in absorbance at $686 \mathrm{~nm}$ for $15 \mathrm{~min}$. One unit of enzymatic activity was defined as the amount of enzyme required to increase the $\mathrm{OD}_{686 \mathrm{~nm}}$ by one unit per minute.

\section{Data analysis}

All data are expressed as the mean \pm SE (standard error). Significant differences in the photosynthetic pigment content, the proportion of chlorophyll degradation products and enzyme activity were evaluated. Changes in the measured biochemical parameters between phenological forms, experimental areas and the years 2007 and 2009 were analysed. Before analysis, the data were checked for normal distribution (Kolmogorov-Smirnov test) and homogeneity of variance (Bartlett's test) (Sokal and Rohlf 1995). Repeated measures ANOVA (RM-ANOVA), with the Tukey test for multiple range analysis as a post hoc test, was used when the data satisfied the requirements of the analysis. In the event of heteroscedasticity and when variables were not normally distributed, the analyses were performed using non-parametric Kruskal-Wallis or U Mann-Whitney tests. Differences were considered significant at $\mathrm{P}<0.05$. Pearson's coefficient of linear correlation or the non-parametric Spearman's coefficient of rank correlation were calculated between the chlorophyll content, the proportion of its degradation products, enzyme activity and temperature. All measurements were tested using Statistica software version 10.0 (StatSoft Inc., Tulsa, OK, USA).

\section{Results}

There were significant differences between beech stands and phenological forms over the course of leaf discoloration during autumn senescence. The two stands differed by approximately $7-10 \mathrm{~d}$ in the date of occurrence of the autumn phenological phases and the proportion of discoloured leaves in the tree crowns. During both growing seasons, the first symptoms of leaf discoloration (5-10\% discoloured leaves) occurred earlier in the Mlynka stand (September 8) than in the Kopce stand (September 16). 


\section{Weather conditions}

The weather conditions in 2007 and 2009 are presented in Fig. 1A and 1B. During the sampling peri- ods, the minimum, average and maximum temperatures were $9.2,14.8$ and $20.2^{\circ} \mathrm{C}$ in 2007 , respectively, and $10.5,15.6$ and $21.0^{\circ} \mathrm{C}$ in 2009 , respectively. The total precipitation in 2007 and 2009 for the period

Table 1. Average monthly temperatures and total precipitation during the sampling periods in 2007 and 2009

\begin{tabular}{|c|c|c|c|c|c|c|c|c|}
\hline \multirow{4}{*}{ Month } & \multicolumn{8}{|c|}{ Year of leaf collection } \\
\hline & \multicolumn{4}{|c|}{2007} & \multicolumn{4}{|c|}{2009} \\
\hline & \multicolumn{3}{|c|}{ Temperature $\left[{ }^{\circ} \mathrm{C}\right]$} & \multirow{2}{*}{$\begin{array}{c}\text { Total precipitation } \\
{[\mathrm{mm}]}\end{array}$} & \multicolumn{3}{|c|}{ Temperature $\left[{ }^{\circ} \mathrm{C}\right]$} & \multirow{2}{*}{$\begin{array}{c}\text { Total precipitation } \\
{[\mathrm{mm}]}\end{array}$} \\
\hline & Min. & Ave. & Max. & & Min. & Ave. & Max. & \\
\hline July & 12.8 & 19.1 & 25.3 & 78.3 & 13.8 & 19.6 & 25.8 & 83.5 \\
\hline August & 12.9 & 18.8 & 24.6 & 77.4 & 12.7 & 18.6 & 24.8 & 53.7 \\
\hline September & 7.2 & 12.6 & 18.0 & 182.9 & 9.6 & 15.2 & 21.0 & 35.5 \\
\hline October & 2.9 & 7.5 & 12.0 & 48.4 & 4.2 & 7.4 & 10.9 & 83.1 \\
\hline Sampling period & 9.2 & 14.8 & 20.2 & 387.0 & 10.5 & 15.6 & 21.0 & 255.8 \\
\hline
\end{tabular}

Min. - minimum temperature, Ave. - average temperature, Max. - maximum temperature.
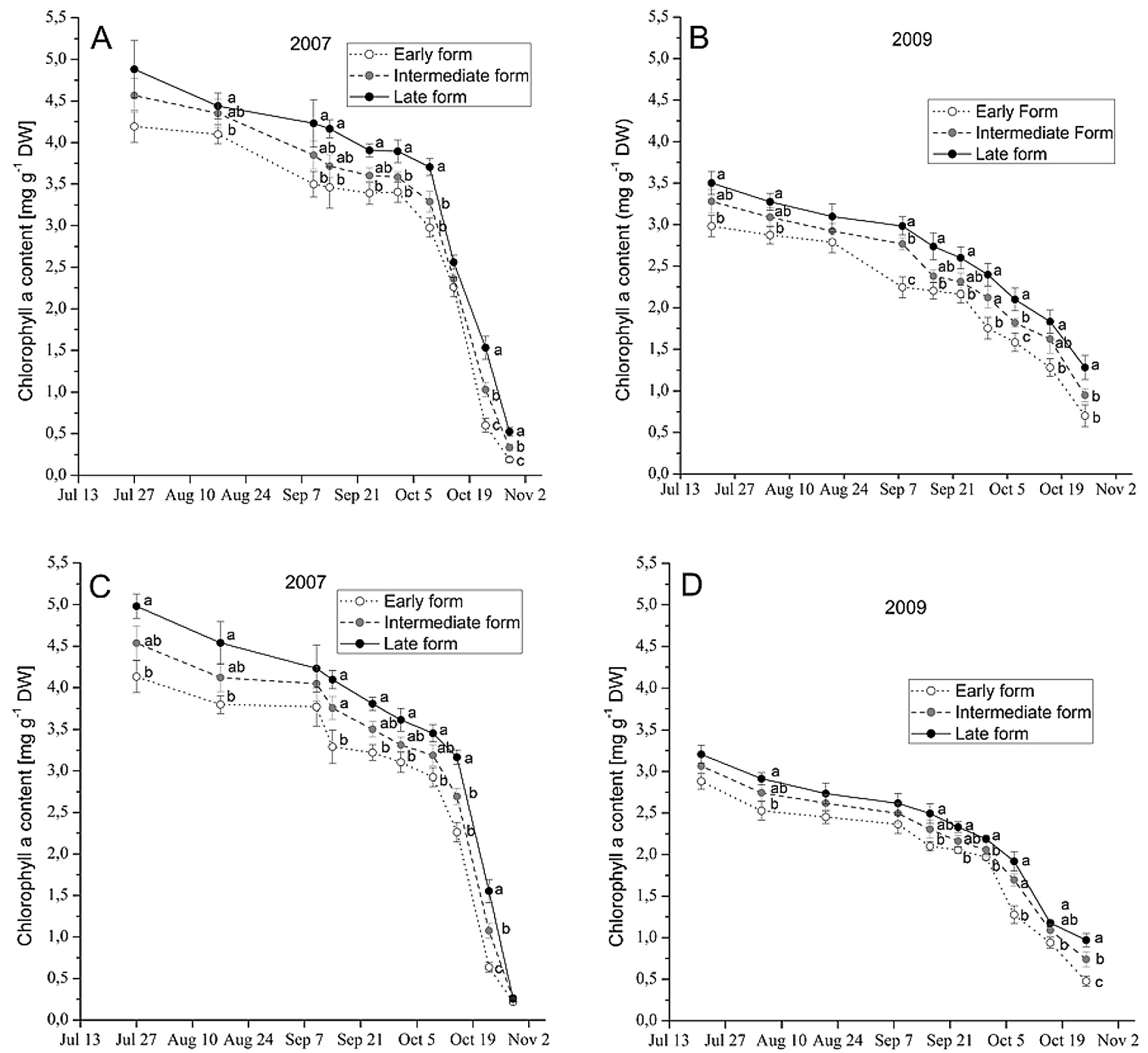

Fig. 2. Changes in chlorophyll a content in autumn leaves from different phenological forms of beech trees (Fagus sylvatica L.). Analyses were performed for two beech stands - Mlynka (A and B) and Kopce (C and D) - in 2007 and 2009. Each point is the mean of 15 measurements $( \pm S E)$. Means denoted by different letters are significantly different at $\mathrm{P}<0.05$ 

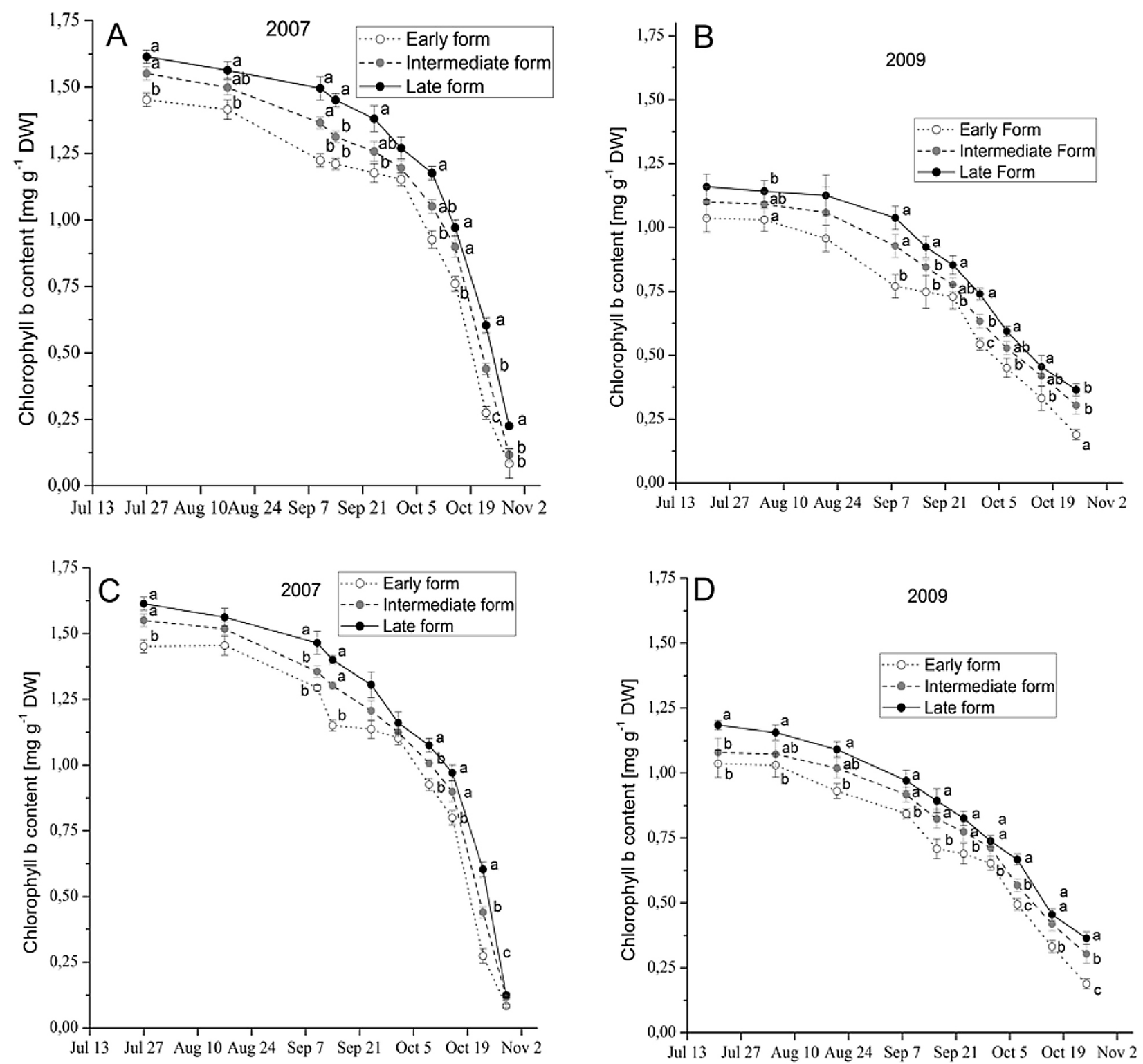

Fig. 3. Changes in chlorophyll b content in autumn leaves from different phenological forms of beech trees (Fagus sylvatica L.). Analyses were performed for two beech stands - Mlynka (A and B) and Kopce (C and D) - in 2007 and 2009. Each point is the mean of 15 measurements $( \pm S E)$. Means denoted by different letters are significantly different at $\mathrm{P}<0.05$.

of July to October was 387 and $256 \mathrm{~mm}$, respectively (Table 1). The minimum temperature conditions in 2007 were primarily above $10^{\circ} \mathrm{C}$ from the beginning of the sampling period through August 23, at which point the minimum temperature began to drop below $10-11^{\circ} \mathrm{C}$ and the maximum temperature fell below $15^{\circ} \mathrm{C}$ (Fig. 1A). After this date, the minimum and maximum temperatures remained at a lower level and averaged approximately 7 and $18^{\circ} \mathrm{C}$, respectively, until October 2 (Fig. 1A). In this month, the minimum and maximum temperature course varied from -2 to $10^{\circ} \mathrm{C}$ and 5 to $18^{\circ} \mathrm{C}$, respectively. The temperature course during the sampling period in 2009 was characterised by higher minimum, average and maximum temperatures (Table 1), a lower and shorter temperature decrease at the beginning of September
(Fig. 1B) and a milder temperature decrease from the beginning to the end of September. However, a sharp drop in temperature occurred at the beginning of October (Fig. 1B). Significant differences (approximately $50 \%$ ) in the total precipitation, as well as the monthly fluctuations between 2007 and 2009, were also detected (Table 1).

\section{Changes in chlorophyll content in autumn-senescing leaves}

In the majority of the leaf collections prior to mid-August, the leaves of the late phenological form contained significantly more chlorophyll a and chlorophyll $b$ than the early form in both sites and growing seasons $(\mathrm{P}<0.05)$ (Figs. 2 and 3$)$. Differences be- 
tween the phenological forms ranged from 12 to $20 \%$ for chlorophyll a and 10 to $13 \%$ for chlorophyll $b$.

Almost in all dates of leaves collection the chlorophyll a and chlorophyll b contents differed significantly among phenological forms, year of sample collection and in the final stage of senescence between studied sites $(\mathrm{P}<0.01)$. The chlorophyll content was significantly greater in 2007 than in 2009. During the period between the end of July and the second half of August in the Mlynka site, chlorophyll a was slowly degraded at a similar rate in all phenological forms. In the Kopce site, the end of this stage of chlorophyll degradation was delayed until the beginning of September (Fig. 2A-2D). This phase of leaf development was designated as the pre-senescence stage. The acceleration of chlorophyll degradation (senescence onset) occurred at the end of August or beginning of September (Fig. 2). The exact timing and dynamics of this process depended on the site (Mlynka, Kopce) and phenological form of the beech individuals (Fig. $2 \mathrm{~A}-2 \mathrm{D})$ as well as on the weather conditions during the particular growing season (Fig. $1 \mathrm{~A}$ and 1B). In the early phenological form, chlorophyll degradation in senescing leaves occurred in three stages. Two stages of rapid chlorophyll degradation were separated by a stage of slow decrease in pigment content. The dates on which these stages began were close to the dates of temperature drops (Fig. 1A-1B, 2A-2D). These stages were less visible in the intermediate form. In the late form, two stages of chlorophyll degradation were identified: a gradual decrease in September and a sharp decrease in October. This form did not exhibit a middle stage of slow chlorophyll decrease. In both growing seasons, the first stage of leaf senescence was associated with a drop in the average temperature below $15^{\circ} \mathrm{C}$. During this stage, the early form was characterized by a higher chlorophyll degradation rate during the temperature drop in both beech stands: the Mlynka site started to senesce at the end of August and first ten days of September (Fig. 2A and 2B), whereas the Kopce site started in the first half of September (Fig. 2C and 2D). Consequently, the phenological forms showed the greatest and most significant differences $(\mathrm{P}<0.01)$ in chlorophyll a content at the end of this stage. In the intermediate and late phenological forms, stage 1 of leaf senescence was delayed in time and exhibited a slower chlorophyll a decrease (Fig. 2). After September 8-10 in the Mlynka site and September 14-16 in the Kopce site, chlorophyll a degradation slowed down in the early form and a period of stabilised chlorophyll a content occurred until the end of September (this period was designated as stage 2 of senescence in the early form). In the other phenological forms, chlorophyll a was degraded more quickly during the second half of September (Fig. 2). The final stage of leaf senescence started between October 1 and October 9 in 2007 or September 23 and September 30 in 2009, depending on the beech site and phenological form (Fig. 2), and was related to a sharp and permanent drop in temperature below $10^{\circ} \mathrm{C}$. During final stage of senescence, chlorophyll a content decreased to an average of $8.7 \%$ in 2007 and $38.3 \%$ in 2009 , relative to the beginning of the stage.

The chlorophyll $b$ degradation profile during leaf senescence was similar to that of chlorophyll a. The main difference was the earlier onset of chlorophyll $\mathrm{b}$ degradation in particular stages of leaf senescence compared with chlorophyll a (Fig. 3A-3D). The result of this phenomenon was a slight increase in the chlorophyll a/b ratio until the beginning of October; however, beech stands and phenological forms did not differ significantly in terms of this feature (data not shown). At the end of the senescence period, the chlorophyll a/b ratio decreased. The differences between the chlorophyll a and chlorophyll b contents in particular phenological forms in both years were significant in a majority of the analysed dates of sample collection, particularly in the periods with temperature decreases $(\mathrm{P}<0.001)$ (Fig. 2A-2D, Fig. 3A-3D). The studied beech stands were characterised by different timing in the beginning of phenological and chlorophyll degradation phases during leaf senescence, which caused significantly different courses in the levels of photosynthetic pigments $(\mathrm{P}<0.01)$.

\section{Changes in the levels of chlorophyll degradation products}

In both stands and in all phenological forms, the fractions of chlorophyllide a in relation to chlorophyll a amounted to approximately $3 \%$ until October 1 (Mlynka stand) or October 9 (Kopce stand), i.e., until the beginning of the final stage of leaf senescence, and then increased to 9-10\% (Fig. 4). The chlorophyllide $b$ fraction was significantly higher than that of chlorophyllide a, amounting to approximately $8-9 \%$ of the chlorophyll b content, and increased to 23-26\% (depending on phenological form) at the end of October (Fig. 5). The phenological forms differed significantly in their chlorophyllide $\mathrm{a}$ and chlorophyllide $\mathrm{b}$ content during the period of intense chlorophyll degradation spurred by the sudden temperature drop at the end of the first half of September and during the final stage of leaf senescence in October (Fig. 4, Fig. 5). The largest increase in chlorophyllide content during the temperature drops occurred in the early phenological form (Fig. 4 and Fig. 5). The late form showed fluctuations in the levels of chlorophyllides only in the final phase of leaf senescence. The percentage of chlorophyllide a relative to the chlorophyll a content was approximately three times lower than the percentage of chlorophyllide $\mathrm{b}$ in relation to chlorophyll b; however, due to the 

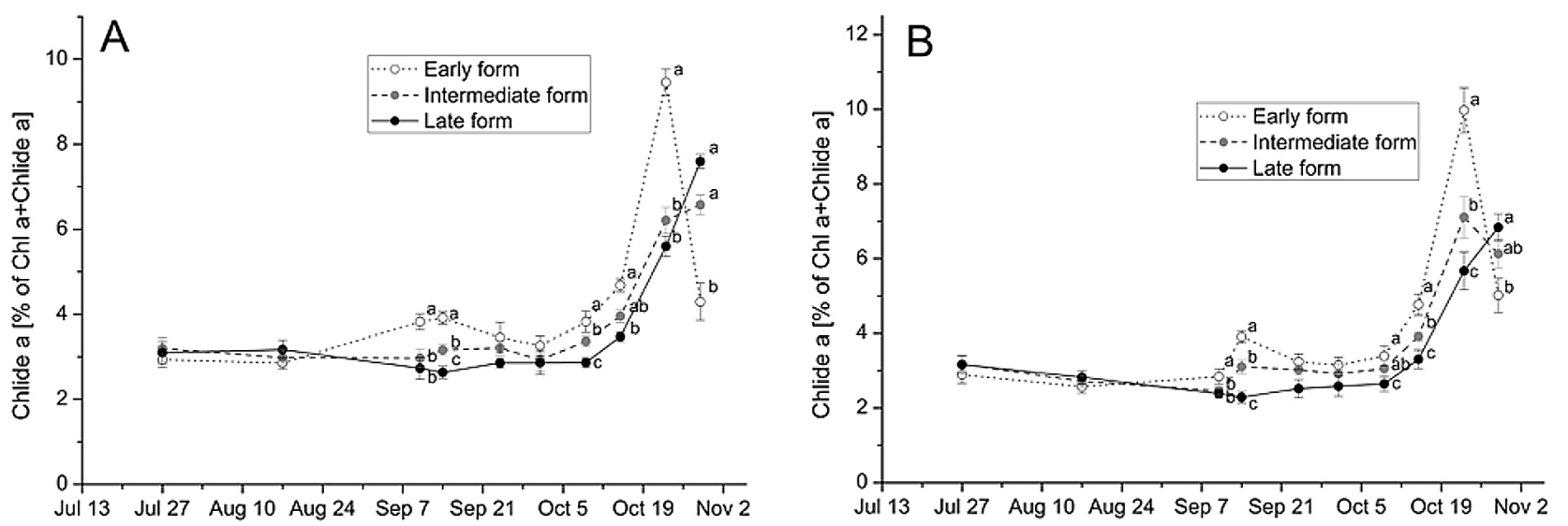

Fig. 4. Chlorophyllide a fraction of chlorophyll a content in senescing leaves of phenological forms of beech trees (Fagus sylvatica L.). Analyses were performed for two beech stands - Mlynka (A) and Kopce (B) - in 2007. Each point is the mean of 15 measurements $( \pm S E)$. Means denoted by different letters are significantly different at $\mathrm{P}<0.05$

much higher chlorophyll a content, the differences between the amounts of degradation products were smaller, though the phenological forms still differed significantly $(\mathrm{P}=0.021)$. Total phaeophytin production was much lower than the total chlorophyllide levels (almost $2-3 \%$ of chlorophyll a and b content depending on beech sites). In both stands, the phaeophytin content decreased until the beginning of October with a short period of increase during the temperature decrease in the first half of September. Phaeophytin content increased slightly in the final stage of senescence, when the temperature dropped below $10^{\circ} \mathrm{C}$ and the rate of chlorophyll degradation was at its highest. Similar to chlorophyllide production, the largest increase in phaeophytin content in September and October was found in the early phenological form (Fig. 4, Fig. 5, Fig. 6).
The proportion of chlorophyll degradation products with respect to the total chlorophyll content reflected the rate of production of chlorophyllide a, chlorophyllide $\mathrm{b}$ and total phaeophytin (Table 2). Analyses revealed that the proportion of chlorophyll degradation products started to increase earlier in Mlynka than in the Kopce stand (by approximately 1 week), which confirmed the earlier date of senescence onset in the Mlynka stand (Table 2). A sudden increase in the proportion of chlorophyll degradation products occurred in the second decade of September (September 10 and September 14) and in the final stage (October 15 to October 23-29, depending on phenological form) of leaf senescence. On these dates, the levels of the degradation products differed significantly between phenological forms $(\mathrm{P}<0.0001)$ and was highest in the early form (Table 2 ).
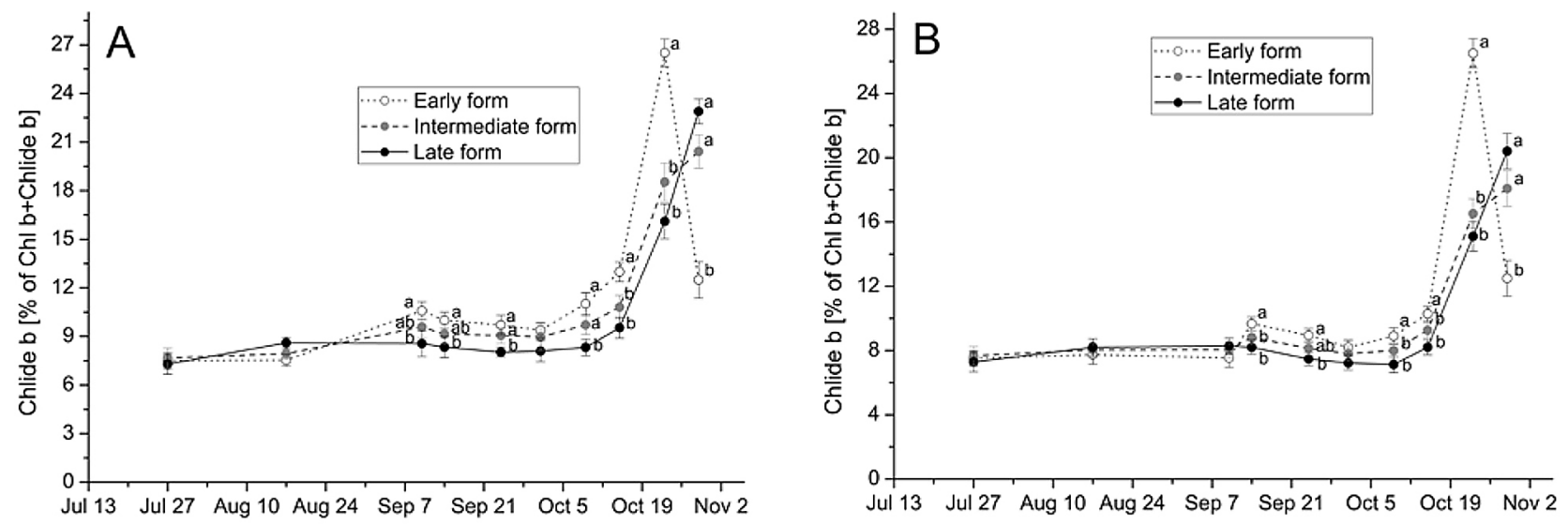

Fig. 5. Chlorophyllide $b$ fraction of chlorophyll b content in senescing leaves of phenological forms of beech trees (Fagus sylvatica L.). Analyses were performed for two beech stands - Mlynka (A) and Kopce (B) - in 2007. Each point is the mean of 15 measurements $( \pm S E)$. Means denoted by different letters are significantly different at $\mathrm{P}<0.05$. 

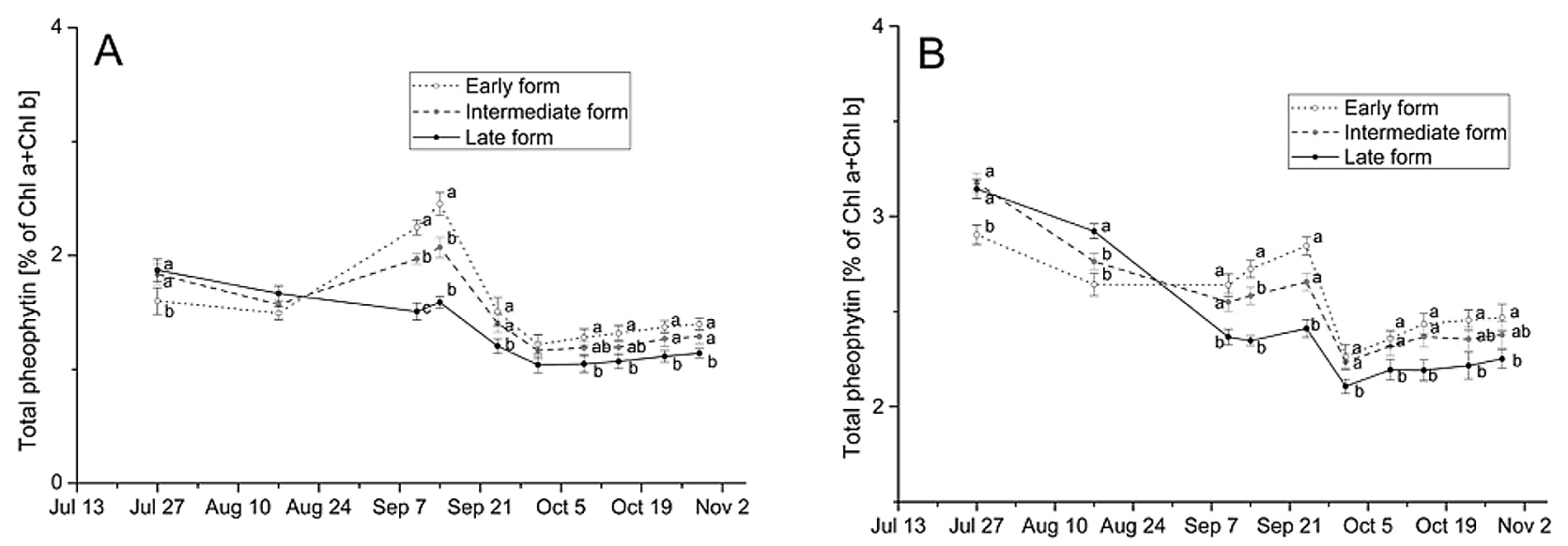

Fig. 6. Total phaeophytin fraction of total green pigments in senescing leaves of phenological forms of beech trees (Fagus sylvatica L.). Analyses were performed for two beech stands - Mlynka (A) and Kopce (B) - in 2007. Each point is the mean of 15 measurements $( \pm S E)$. Means denoted by different letters are significantly different at $\mathrm{P}<0.05$

Table 2. Proportions (\%) of chlorophyll degradation products (sum of chlorophyllide a and b and total phaeophytin) in total green pigments (chlorophyll a and chlorophyll b) in senescing leaves of phenological forms of beech in 2007 in the Mlynka and Kopce sites

\begin{tabular}{|c|c|c|c|c|c|c|}
\hline \multirow{3}{*}{ Date } & \multicolumn{6}{|c|}{ Proportion of chlorophyll degradation products in total green pigments $[\% \pm \mathrm{SE}]$} \\
\hline & \multicolumn{3}{|c|}{ Mlynka site } & \multicolumn{3}{|c|}{ Kopce site } \\
\hline & Early form & Intermediate form & Late form & Early form & Intermediate form & Late form \\
\hline $2007-07-27$ & $5.71 \pm 0.17^{\mathrm{a}}$ & $6.17 \pm 0.24^{\mathrm{a}}$ & $6.01 \pm 0.25^{\mathrm{a}}$ & $7.00 \pm 0.28^{a}$ & $7.50 \pm 0.30^{\mathrm{a}}$ & $7.31 \pm 0.34^{a}$ \\
\hline 2007-08-17 & $5.55 \pm 0.12^{\mathrm{a}}$ & $5.82 \pm 0.22^{\mathrm{a}}$ & $6.25 \pm 0.14^{\mathrm{a}}$ & $6.65 \pm 0.26^{\mathrm{a}}$ & $6.91 \pm 0.27^{\mathrm{ab}}$ & $7.12 \pm 0.28^{b}$ \\
\hline 2007-09-10 & $7.82 \pm 0.33^{\mathrm{a}}$ & $6.67 \pm 0.34^{b}$ & $5.76 \pm 0.39^{b}$ & $6.68 \pm 0.21^{\mathrm{a}}$ & $6.41 \pm 0.34^{a}$ & $6.26 \pm 0.28^{a}$ \\
\hline 2007-09-14 & $7.95 \pm 0.34^{\mathrm{a}}$ & $6.79 \pm 0.31^{b}$ & $5.70 \pm 0.32^{b}$ & $8.12 \pm 0.28^{a}$ & $7.16 \pm 0.27^{\mathrm{ab}}$ & $6.14 \pm 0.23^{b}$ \\
\hline 2007-09-24 & $6.57 \pm 0.17^{a}$ & $6.13 \pm 0.11^{\mathrm{a}}$ & $5.41 \pm 0.09^{\mathrm{a}}$ & $7.57 \pm 0.26^{a}$ & $6.98 \pm 0.25^{\mathrm{a}}$ & $6.20 \pm 0.20^{\mathrm{a}}$ \\
\hline 2007-10-01 & $6.03 \pm 0.15^{a}$ & $5.60 \pm 0.15^{\mathrm{a}}$ & $5.19 \pm 0.08^{\mathrm{a}}$ & $6.74 \pm 0.29^{a}$ & $6.39 \pm 0.29^{a}$ & $5.82 \pm 0.29^{a}$ \\
\hline 2007-10-09 & $6.81 \pm 0.16^{\mathrm{a}}$ & $6.09 \pm 0.25^{\mathrm{ab}}$ & $5.22 \pm 0.30^{\mathrm{b}}$ & $7.53 \pm 0.31^{\mathrm{a}}$ & $6.71 \pm 0.28^{a}$ & $5.90 \pm 0.28^{a}$ \\
\hline 2007-10-15 & $8.09 \pm 0.31^{\mathrm{a}}$ & $7.04 \pm 0.26^{b}$ & $6.21 \pm 0.16^{b}$ & $8.64 \pm 0.35^{\mathrm{a}}$ & $7.62 \pm 0.29^{\mathrm{ab}}$ & $6.64 \pm 0.28^{b}$ \\
\hline 2007-10-23 & $16.17 \pm 0.34^{\mathrm{a}}$ & $11.16 \pm 0.57^{b}$ & $9.68 \pm 0.50^{\mathrm{b}}$ & $17.42 \pm 0.63^{\mathrm{a}}$ & $12.20 \pm 0.62^{\mathrm{b}}$ & $10.53 \pm 0.59^{b}$ \\
\hline 2007-10-29 & $8.18 \pm 0.58^{a}$ & $11.43 \pm 0.50^{\mathrm{a}}$ & $13.32 \pm 0.37^{\mathrm{a}}$ & $9.53 \pm 0.67^{a}$ & $12.24 \pm 0.46^{\mathrm{a}}$ & $13.46 \pm 0.51^{a}$ \\
\hline
\end{tabular}

Different letters indicate significant differences $(\mathrm{P}<0.01)$ by Tukey's Multiple Range test.

\section{Chlorophyllase and Mg-dechelatase activity}

Phenological forms and beech stands differed significantly in chlorophyllase activity $(\mathrm{P}<0.0001)$. During the pre-senescence phase, the late phenological form showed the highest and the fastest decline of enzyme activity (Fig. 7). A critical date was the sudden temperature decline at the beginning of September, which induced a significant increase in chlorophyllase activity, which was highest in the early phenological form. Similar to the dynamics of chlorophyll and chlorophyllides contents, chlorophyllase activity changed during the stages associated with the temperature pattern. The late form showed a slower and more stable increase of chlorophyllase activity (Fig. 7). A correlation analysis showed that chlorophyllase activity depended on a 7-day average of minimum and maximum temperatures (Table 4). The highest correlation coefficient was found in the early phenological form, wherein the correlation coefficient for minimum temperature was higher than that for maximum temperature.

The proportion of total chlorophyllides was largely correlated with the decrease in the chlorophyll $\mathrm{a}$ and chlorophyll $\mathrm{b}$ contents in both beech stands. The values of the Pearson correlation coefficients for the chlorophyll content and proportion of chlorophyllides depended on early, intermediate and late phenological forms and for the two studied periods, amounted on average to similar values for the chlorophyll a and b: $-0.90,-0.87$ and -0.75 , respectively $(\mathrm{P}<0.05)$.

Mg-dechelatase activity was low during leaf senescence. The only period of higher Mg-dechelatase activity was the beginning of September, after the temperature decrease (during initial stage of senescence); however, phenological forms did not differ significantly in terms of Mg-dechelatase activity. 

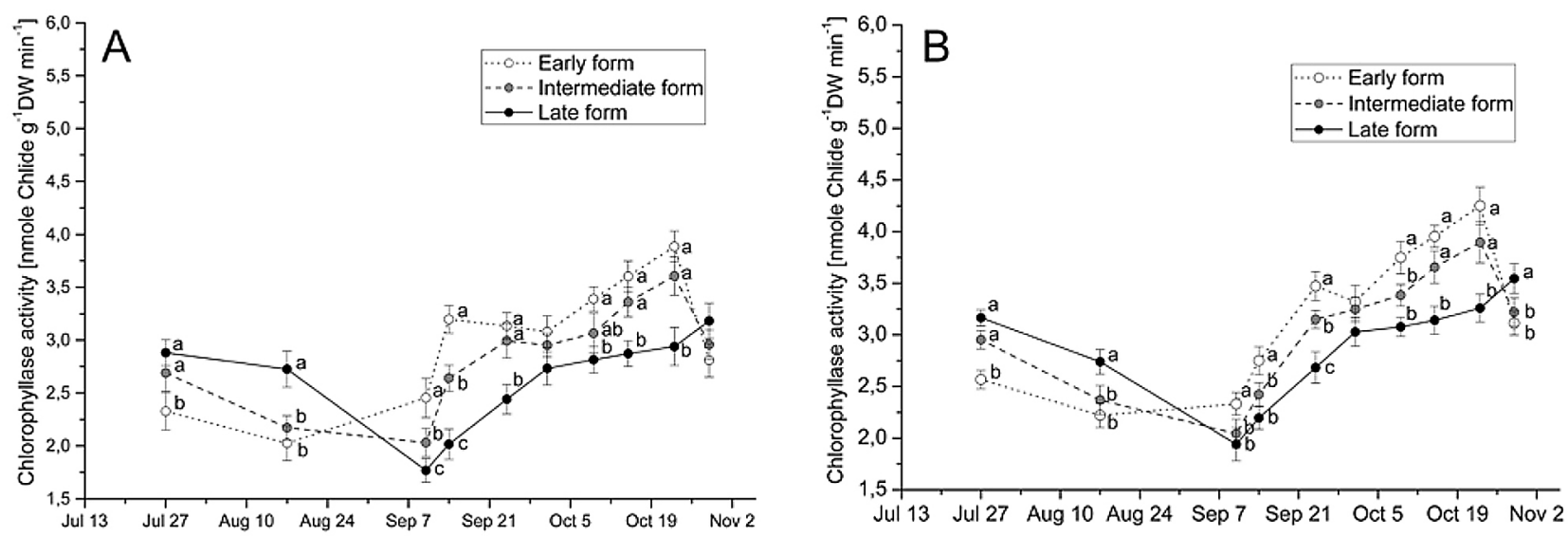

Fig. 7. Chlorophyllase activity in senescing leaves of phenological forms of beech trees (Fagus sylvatica L.). Analyses were performed for two beech stands - Mlynka (A) and Kopce (B) - in 2007. Each point is the mean of 15 measurements $( \pm S E)$. Means denoted by different letters are significantly different at $\mathrm{P}<0.05$

\section{Temperature effect on chlorophyll content, degradation product levels and chlorophyll-degrading enzyme activities}

To evaluate the influence of the level and the fluctuations of temperature on the course of photosynthetic pigment degradation (and thus leaf senescence), Pearson or Spearman correlation coefficients were calculated. A correlation analysis of the chlorophyll content and the minimum, maximum and average temperature was performed on the two beech sides during two vegetation periods, whereas temperature effects on the level of chlorophyll degradation products and activity of chlorophyllase were analysed in the two beech sides during one vegetation period. The results showed a significant effect of temperature on the chlorophyll a and chlorophyll b contents (Table $3)$. In most cases, the correlation coefficients tend- ed to be higher for the maximum temperature than for the minimum temperature. In both studied sites and vegetation periods, the early phenological form had the highest correlation coefficients. In the later phenological forms, the correlation coefficients were smaller. The effect of temperature on chlorophyll content was confirmed by the correlation coefficients between temperature and the chlorophyll degradation products (Table 4). As in the case of photosynthetic pigments, the correlation coefficients for the degradation products were highest for the early phenological form in both beech stands. The coefficients were also higher for the maximum temperature than for the minimum temperature. The differences between the coefficients were greater in the later phenological form (Table 4). Due to the low activity of Mg-dechelatase during leaf senescence, this measure was omitted from the correlation analysis.

Table 3. Spearman rank correlation coefficients between 7-day average temperatures and chlorophyll a and chlorophyll b content in the leaves of three phenological forms of beech. Correlation analysis was performed for the years 2007 and 2009

\begin{tabular}{|c|c|c|c|c|c|c|}
\hline \multicolumn{7}{|c|}{ Beech site } \\
\hline \multicolumn{4}{|c|}{ Mlynka } & \multicolumn{3}{|c|}{ Kopce } \\
\hline \multicolumn{7}{|c|}{ Phenological form } \\
\hline & Early & Intermediate & Late & Early & Intermediate & Late \\
\hline \multicolumn{7}{|c|}{ Chlorophyll a } \\
\hline $\mathrm{t}_{\min .}$ & $0.52^{* *}$ & $0.49^{*}$ & $0.44^{*}$ & $0.52^{* *}$ & $0.49^{*}$ & $0.45^{*}$ \\
\hline $\mathrm{t}_{\max }$ & $0.62^{* *}$ & $0.58^{* *}$ & $0.55^{* *}$ & $0.58^{* *}$ & $0.54^{*}$ & $0.51^{*}$ \\
\hline$t_{\text {average }}$ & $0.58^{* *}$ & $0.53^{* *}$ & $0.49^{* *}$ & $0.56^{*}$ & $0.53^{*}$ & $0.50^{*}$ \\
\hline \multicolumn{7}{|c|}{ Chlorophyll b } \\
\hline $\mathrm{t}_{\text {min. }}$ & $0.63^{* *}$ & $0.60^{* *}$ & $0.57^{*}$ & $0.65^{* *}$ & $0.60^{*}$ & $0.59 *$ \\
\hline $\mathrm{t}_{\max }$ & $0.61^{* *}$ & $0.62^{* *}$ & $0.55^{*}$ & $0.61^{* *}$ & $0.62^{* *}$ & $0.72^{* *}$ \\
\hline$t_{\text {average }}$ & $0.60^{* *}$ & $0.61^{* *}$ & $0.54^{*}$ & $0.62 * *$ & $0.61^{* *}$ & $0.60^{* *}$ \\
\hline
\end{tabular}

* $-\mathrm{P}<0.05,{ }^{* *}-\mathrm{P}<0.01$. 
Table 4. Pearson rank correlation coefficients between 7-day average temperatures and chlorophyllide a, chlorophyllide b, total phaeophytin and chlorophyllase activity in the leaves of three phenological forms of beech. Correlation analysis was performed for the year 2007

\begin{tabular}{|c|c|c|c|c|c|c|}
\hline \multicolumn{7}{|c|}{ Beech site } \\
\hline \multicolumn{4}{|c|}{ Mlynka } & \multicolumn{3}{|c|}{ Kopce } \\
\hline \multicolumn{7}{|c|}{ Phenological form } \\
\hline & Early & Intermediate & Late & Early & Intermediate & Late \\
\hline \multicolumn{7}{|c|}{ Chlorophyllide a } \\
\hline $\mathrm{t}_{\min }$ & -0.52 & -0.45 & -0.37 & -0.59 & -0.52 & -0.37 \\
\hline$t_{\max }$ & $-0.69^{*}$ & $-0.64^{*}$ & -0.60 & $-0.67^{*}$ & $-0.65^{*}$ & -0.57 \\
\hline$t_{\text {average }}$ & $-0.62^{*}$ & $-0.61^{*}$ & -0.52 & $-0.66^{*}$ & $-0.62^{*}$ & -0.51 \\
\hline \multicolumn{7}{|c|}{ Chlorophyllide b } \\
\hline$t_{\text {min. }}$ & -0.60 & -0.45 & -0.37 & -0.55 & -0.45 & -0.34 \\
\hline$t_{\max }$ & $-0.67^{*}$ & $-0.66^{*}$ & -0.59 & $-0.59^{*}$ & $-0.65^{*}$ & -0.61 \\
\hline$t_{\text {average }}$ & -0.67 & $-0.59^{*}$ & -0.52 & $-0.60^{*}$ & $-0.60^{*}$ & -0.59 \\
\hline \multicolumn{7}{|c|}{ Phaeophytin } \\
\hline $\mathrm{t}_{\text {min. }}$ & -0.47 & -0.44 & -0.35 & -0.62 & -0.43 & 0.00 \\
\hline$t_{\max }$ & $-0.80^{* *}$ & $-0.77^{*}$ & $-0.66^{*}$ & $-0.74^{*}$ & -0.52 & -0.20 \\
\hline$t_{\text {average }}$ & $-0.69^{*}$ & -0.65 & -0.55 & $-0.72^{*}$ & -0.51 & -0.12 \\
\hline \multicolumn{7}{|c|}{ Chlorophyllase } \\
\hline $\mathrm{t}_{\min }$ & $-0.89 * * *$ & $-0.83^{* *}$ & -0.27 & $-0.90^{* * *}$ & $-0.83^{* *}$ & -0.27 \\
\hline$t_{\max }$ & $-0.68^{*}$ & -0.50 & -0.09 & $-0.69 *$ & -0.49 & -0.10 \\
\hline$t_{\text {average }}$ & $-0.80^{* *}$ & $-0.68^{*}$ & -0.17 & $-0.82^{*}$ & $-0.67^{*}$ & -0.18 \\
\hline
\end{tabular}

${ }^{*}-\mathrm{P}<0.05,{ }^{* *}-\mathrm{P}<0.01,{ }^{* * *}-\mathrm{P}<0.001$.

\section{Discussion}

The main symptoms of leaf senescence are the decreases in chlorophyll and protein levels. Changes in the total chlorophyll, protein and amino acid contents in leaves are negatively correlated with senescing intensity and are widely used as a metabolic indicator to determine the timing and phases of leaf senescence (Diaz et al. 2005; Hortensteiner 2006; Kraj 2014). It is well known that autumn senescence in most deciduous trees is regulated by photoperiod and temperature, which are the most important abiotic drivers of this process (Keskitalo et al. 2005). These factors play an important role in triggering beech leaf senescence (Delpierre et al. 2009; Estrella and Menzel 2006; Vitasse et al. 2011), and it is somewhat difficult to separate the effects of these factors on the timing and course of leaf senescence.

In the present study, we demonstrated the effect of phenological forms on the profile of chlorophyll degradation during natural leaf senescence. Leaf samples were collected in two beech stands for two years to characterise the effects of climatic conditions on chlorophyll degradation. This approach made it possible to date the beginning and the course of senescence for the phenological forms of beech. Because the chlorophyll level in leaves varies depending primarily on light intensity, the samples were collected from areas of the tree crowns uniformly exposed to the sun. The chosen method of leaf collection pro- duced representative samples for each particular phenological form.

The greater quantity of chlorophyll during the pre-senescence stage in the late form than in the early form confirmed the results of previous research conducted at the Mlynka site in 2005 and 2008 (Kraj 2014). Even with the reduced chlorophyll content in 2009 relative to 2007 , the late form had greater pigment content. These properties of beech phenological forms, based on four years of observations and two populations (the present results), suggest that these differences are genetically determined. This finding should be confirmed in larger numbers of beech populations. The differences between 2007 and 2009 in the levels of chlorophyll appear to be the result of both the temperature trends and the amount and distribution of rainfall during the sampling periods. Beech trees are very sensitive to drought and require a large quantity of evenly distributed precipitation. We would like to emphasize that the lower amount of total precipitation during the sampling period in 2009 could have a direct effect on both the chlorophyll level and the yellowing rate of leaves, which is negatively correlated with September precipitation (Cufar et al. 2008; Škvareninová and Snopková 2011).

The respective contributions of photoperiod and temperature in triggering leaf senescence, and thus chlorophyll degradation, differ in different tree species (Fracheboud et al. 2009; Škvareninová and 
Snopková 2011). For example, the main factor determining the date of senescence onset in aspen is photoperiod (Fracheboud et al. 2009; Keskitalo et al. 2005), whereas in oak, photoperiod is of secondary importance (Delpierre et al. 2009). In the present study the profiles of chlorophyll content and its degradation products support the conclusion that the main factor determining the beginning of the senescence stages was temperature change. Temperature induces leaf senescence, but only in conjunction with the appropriate day length; it cannot be the sole triggering factor in senescence. The factor associated with temperature that triggers leaf senescence may also be radiation. Garcia-Plazaola and Bacerril (2001) showed that natural leaf senescence in beech occurred first in leaves with greater exposure to the sun. Entry into each senescence stage was caused by a sudden drop in temperature. In the pre-senescence stage, a significant temperature drop did not cause a considerable decrease in chlorophyll. However, a sudden drop in temperature in late August and early September, when the appropriate photoperiod occurred, caused entry into the first stage of leaf senescence. A second temperature drop from the end of September to the beginning of October caused entry into the final stage of leaf senescence. Similar behaviours in all phenological forms in terms of chlorophyll degradation were also observed in 2005 and 2008 in the same experimental plot in the Mlynka stand (Kraj 2014).

The highest correlation coefficients and the highest rate of chlorophyll decrease during the temperature drops in the early phenological form indicate that this form is more sensitive to temperature drops than the late form, resulting in chlorophyll degradation immediately after temperatures drop. These differences between phenological forms of beech determined the dates of the beginning of the leaf senescence stages as well as their lengths. The resulting data suggest that temperature changes occurring in tandem with the appropriate photoperiod induce and then regulate the leaf senescence process, wherein the effect is much greater in the early than in the late phenological form. The critical photoperiod revealed in the present study occurred in late August and early September (approximately $13 \mathrm{~h}$ ) and caused the onset of the first stage of leaf senescence. This finding is in agreement with those of Schuster et al. (2014), who showed that the critical photoperiod for senescence in German beech populations is between 11 and $13.7 \mathrm{~h}$, depending on the population location. Presumably, the impact of photoperiod and temperature in the first stage, most visible in early form, was reversible in September. A temperature increase or stabilisation after the sudden drop during initial stage caused chlorophyll degradation (leaf senescence) to slow down, particularly in the early form, despite the further reduction in day length. In the final stage of senescence, chlorophyll degradation was rapid and irreversible, regardless of temperature fluctuations. The differential effect of temperature on the behaviour of the phenological forms was much smaller at this stage compared with the earlier stages. It seems that beech leaves passed a second photoperiod threshold at the beginning of October. An important aspect of senescence is that leaves must be competent to respond to and be regulated by the photoperiod. The competency of leaves to the senescence process and the role of leaf competence in determining the progression of senescence in trees are still not well understood. Leaf senescence in European aspen is initiated by photoperiod, but this process is not initiated until the leaves are competent to senesce, a process that is related to carbohydrate status and is influenced by growth arrest and dormancy. As long as photoassimilates are transferred to other parts of the tree from the leaves, it will be highly adaptive for a tree to maintain photosynthetic activity in the leaves; however, when the sink strength decreases, the leaves reach a state in which senescence may begin once the critical photoperiod has been perceived (Fracheboud et al. 2009). In the present study, this role may be played by the second critical photoperiod occurring at the beginning of October.

According to our results, the rate of the loss of green colour during leaf senescence in beech was associated with the rate of chlorophyllide and phaeophytin production. To our knowledge, there are no published studies referring to the activities of chlorophyllase and Mg-dechelatase responsible for the initial steps of chlorophyll breakdown during the natural senescence of beech leaves (http://www.brenda-enzymes.org). The chlorophyllase and Mg-dechelatase activities during leaf senescence reflects various types of leaf senescence. In barley (Sabater and Rodriguez 1978) and in species of cherries (Sytykiewicz et al. 2013), chlorophyllase activity increased, whereas in wheat (Ben-Yaakov et al. 2006) and ginkgo (Tang et al. 2000), the activity of this enzyme decreased. The Mg-dechelation activity was found to increase with the progress of leaf senescence in ginkgo (Tang et al. 2000), whereas its activity decreased in oilseed rape cotyledons (Vicentini et al. 1995); however, to date, this enzyme has only been characterised to a small degree. The present data revealed both an increase in the production of chlorophyllides, providing evidence for chlorophyllase activity in vivo, and an increase in enzyme activity in in vitro assays. Both biochemical analyses showed significant differences in the phenological forms of beech, wherein the early form was characterised by higher levels of chlorophyll degradation products and chlorophyllase activity. Generally, chlorophyllase plays a central role in chlorophyll catabolism, and its up-regulation should be expected 
during leaf senescence (Gepstein et al. 2003). Chlorophyllase, which is a chloroplastic enzyme, may function throughout all phases of leaf development, including senescence. This enzyme resides in the inner envelope of the chloroplast (Matile et al. 1997), but in most leaf senescence systems, it behaves similarly to thylakoid proteins. The degradation and remobilisation of chloroplast proteins do not cause decreases in the amount and activity of this enzyme in senescing leaves (Hirschfeld and Goldschmidt 1983) because the degradation of thylakoid proteins occurs only in the final phase of senescence. This finding was confirmed in the present study, which showed a decrease in the activity of chlorophyllase at the end of the final phase of leaf senescence.

Low Mg-dechelatase activity was detected, though the phaeophytin content was higher than that observed by Garcia-Plazaola and Becerril (2001), who reported that phaeophytin in beech leaves reached approximately $1 \%$ of chlorophyll content. The mechanism of the Mg-dechelation of chlorophyll is rather poorly understood, and two types of activity have been identified in plants: Mg-dechelation may be catalysed by Mg-dechelatase, or it may be associated with metal-chelating substances (Hortensteiner 2006). Some findings suggest that $\mathrm{Mg}$-dechelatase should be regarded as a heat-stable polypeptidic catalyst with a low molecular weight rather than as a typical enzyme (Costa et al. 2002). The fact that phaeophytin reached levels of 2-3\% supports the possibility of $\mathrm{Mg}$ release by metal-chelating substances.

In conclusion, we found that the main factor that induces autumn senescence in beech is temperature drop accompanied by the appropriate photoperiod. Leaf senescence occurred in two or three stages, depending of phenological form, which started in late August and early September after the occurrence of the critical day length of approximately $13 \mathrm{~h}$. Phenological form senescence was differentially induced and regulated by temperature. The early phenological form of beech exhibited higher temperature sensitivity than the late form. The first stage of leaf senescence in this form could be slowed down in September if the tree was exposed to a higher temperature, whereas the final stage of senescence in October was irreversible. It was also found that chlorophyll degradation during senescence in beech was associated with an increase in chlorophyllase activity, whereas Mg-dechelating processes were very low. Further examination of the temperature and photoperiod regulation of beech senescence onset, the partitioning of leaf competency in this process and the biochemical and molecular regulation of chlorophyllase activity is necessary to understand the mechanisms involved in regulating leaf senescence.

\section{Acknowledgments}

This study was supported by the Agricultural University in Cracow (Project number: DS 3414).

I would like to acknowledge the anonymous reviewers for their valuable comments.

\section{References}

Ben-Yaakov E., Harpaz-Saadi S., Galili D., Eyal Y., Goldschmidt E. 2006. The relationship between chlorophyllase activity and chlorophyll degradation during the course of leaf senescence in various plant species. Israel Journal of Plant Sciences 54: 129-135.

Coleman G.D., Englert J.M., Chen T.H.H., Fuchigami L.H. 1993. Physiological and environmental requirements for poplar (Populus deltoides) bark storage protein degradation. Plant Physiology 102: 53-59.

Costa M.L., Civello P.M., Chaves A.R., Martinez G.A. 2002. Characterization of Mg-dechelatase activity obtained from Fragaria $\times$ ananassa fruit. Plant Physiology and Biochemistry 40: 111-118.

Cufar K., Prislan P., de Luis M., Gricar J. 2008. Treering variation, wood formation and phenology of beech (Fagus sylvatica) from a representative site in Slovenia, SE Central Europe. Trees - Structure and Function 22: 749-758.

Delpierre N., Dufrene E., Soudani K., Ulrich E., Cecchini S., Boe J., Francois C. 2009. Modelling interannual and spatial variability of leaf senescence for three deciduous tree species in France. Agricultural and Forest Meteorology 149: 938-948.

Diaz C., Purdy S., Christ A., Morot-Gaudry J.F., Wingler A., Masclaux-Daubresse C. 2005. Characterization of markers to determine the extent and variability of leaf senescence in Arabidopsis. A metabolic profiling approach. Plant Physiology 138: 898-908.

Dolnicki A., Kraj W. 2001. Leaf morphology and the dynamics of frost-hardiness of shoots in two phenological forms of European beech (Fagus sylvatica L.) from Southern Poland. Electronic Journal of Polish Agricultural Universities 4, (http://www.ejpau.media.pl/volume4/issue2/forestry/art-01.html).

Estrella N., Menzel A. 2006. Responses of leaf colouring in four deciduous tree species to climate and weather in Germany. Climate Research 32: 253-267.

Fracheboud Y., Luquez V., Bjorken L., Sjodin A., Tuominen H., Jansson S. 2009. The control of autumn senescence in European aspen. Plant Physiology 149: 1982-1991. 
Garcia-Plazaola J.I., Becerril J.M. 2001. Seasonal changes in photosynthetic pigments and antioxidants in beech (Fagus sylvatica) in a Mediterranean climate: implications for tree decline diagnosis. Australian Journal of Plant Physiology 28: 225-232.

Gepstein S., Sabehi G., Carp M.J., Hajouj T., Nesher M.F., Yariv I., Dor C., Bassani M. 2003. Largescale identification of leaf senescence-associated genes. The Plant Journal 36: 629-642.

Hejtmánek J. 1956. The early and late-flushing forms of beech. Lesne Prace 35: 167-171.

Hirschfeld K.R., Goldschmidt E.E. 1983. Chlorophyllase activity in chlorophyll-free citrus chromoplasts. Plant Cell Reports 2: 117-118.

Hortensteiner S. 2006. Chlorophyll degradation during senescence. Annual Review of Plant Biology 57: 55-77.

Iriyama K., Ogura N., Takamiya A. 1974. A simple method for extraction and partial purification of chlorophyll from plant material, using dioxane. The Journal of Biochemistry 76: 901-904.

Janave M.T. 1997. Enzymic degradation of chlorophyll in cavendish bananas: In vitro evidence for two independent degradative pathways. Plant Physiology and Biochemistry 35: 837-846.

Keskitalo J., Bergquist G., Gardestrom P., Jansson S. 2005. A cellular timetable of autumn senescence. Plant Physiology 139: 1635-1648.

Kraj W. 2014. Proteolytic activity and nitrogen remobilisation in senescing leaves of phenological forms of Fagus sylvatica. Dendrobiology 72: 163176.

Kraj W., Sztorc A. 2009. Genetic structure and variability of phenological forms in the European beech (Fagus sylvatica L.). Annals of Forest Science 66: 203.

Lichtenthaler H.K., Wellburn A.R. 1983. Determination of total carotenoids and chlorophylls $\mathrm{a}$ and $\mathrm{b}$ of leaf in different solvents. Biochemical Society Transactions 11: 591-592.

Lim P.O., Kim H.J., Nam H.G. 2007. Leaf senescence. Annual Review of Plant Biology 58: 115-136.

Matile P., Hortensteiner S., Thomas H., Krautler B. 1996. Chlorophyll breakdown in senescent leaves. Plant Physiology 112: 1403-1409.

Matile P., Schellenberg M., Vicentini F. 1997. Localization of chlorophyllase in the chloroplast envelope. Planta 201: 96-99.

Menzel A. 2003. Plant phenological anomalies in Germany and their relation to air temperature and NAO. Climatic Change 57: 243-263.

Morecroft M.D., Stokes V.J., Morison J.I.L. 2003. Seasonal changes in the photosynthetic capacity of canopy oak (Quercus robur) leaves: the impact of slow development on annual carbon uptake.
International Journal of Biometeorology 47: 221226.

Perkins H.J., Roberts D.W.A. 1962. Purification of chlorophylls, pheophytins and pheophorbides for specific activity determinations. Biochimica et $\mathrm{Bi}-$ ophysica Acta 58: 486-498.

Porra R.J., Thompson W.A., Kriedemann P.E. 1989. Determination of accurate extinction coefficients and simultaneous equations for assaying chlorophylls $\mathrm{a}$ and $\mathrm{b}$ extracted with four different solvents: verification of the concentration of chlorophyll standards by atomic absorption spectroscopy. Biochimica et Biophysica Acta (BBA) Bioenergetics 975: 384-394.

Sabater B., Rodriguez M.T. 1978. Control of chlorophyll degradation in detached leaves of barley and oat through effect of kinetin on chlorophyllase levels. Physiologia Plantarum 43: 274-276.

Schieber B. 2006. Spring phenology of European beech (Fagus sylvatica L.) in a submountain beech stand with different stocking in 1995-2004. Journal of Forest Science 52: 208-216.

Schuster C., Kirchner M., Jakobi G., Menzel A. 2014. Frequency of inversions affects senescence phenology of Acer pseudoplatanus and Fagus sylvatica. International Journal of Biometeorology 58: 485498.

Sokal R.R., Rohlf FJ. 1995. Biometry: the principles and practice of statistics in biological research. W.H. Freeman and Company, New York.

Srivastava L.M. 2002. Vegetative storage protein, tuberization, senescence, and abscission. In: Plant growth and development. Hormones and environment. Academic Press, San Diego, pp. 473-520.

Stachak A. 1965. Fenologia buka zwyczajnego na tle warunków siedliskowych w Puszczy Bukowej pod Szczecinem w latach 1957-1961. Szczecińskie Towarzystwo Naukowe, Wydział Nauk Przyrodniczo-Rolniczych, Szczecin, pp 1-100.

Sytykiewicz H., Sprawka I., Czerniewicz P., Sempruch C., Leszczyński B., Sikora M. 2013. Biochemical characterisation of chlorophyllase from leaves of selected Prunus species - A comparative study. Acta Biochimica Polonica 60: 457-465.

Škvareninová J., Snopková Z. 2011. The development of phenological stages of European beech (Fagus sylvatica L.) in Slovakia during the period of 19962010. In: Bioclimate: Source and Limit of Social. Šiška B., Hauptvogl M., Eliašová M. (eds.). Development International Scientific Conference, 6-9 September 2011, Topolčianky, Slovakia.

Takamiya K.I., Tsuchiya T., Ohta H. 2000. Degradation pathway (s) of chlorophyll: what has gene cloning revealed? Trends in Plant Science 5: 426431.

Tang L., Okazawa A., Fukusaki E., Kobayashi A. 2000. Removal of magnesium by Mg-dechelatase 
is a major step in the chlorophyll-degrading pathway in Ginkgo biloba in the process of autumnal tints. Zeitschrift für Naturforschung 55: 923-926.

Vernon L.P. 1960. Spectrophotometric determination of chlorophylls and pheophytins in plant extracts. Analytical Chemistry 32: 1144-1150.

Vicentini F., Iten F., Matile P. 1995. Development of an assay for $\mathrm{Mg}$-dechelatase of oilseed rape cot- yledons, using chlorophyllin as the substrate. Physiology Plantarum 94: 57-63.

Vitasse Y., Francois C., Delpierre N., Dufrene E., Kremer A., Chuine I., Delzon S. 2011. Assessing the effects of climate change on the phenology of European temperate trees. Agricultural and Forest Meterology 151: 969-980. 